Erato aparece acompañadas de Cupido. Cupido promueve un Amor Virtuoso, pues se presenta sin sus flechas. La castidad triunfa con Orfeo retirado en Ródope.

Con la palabra, por el oído se fortalece la Fe católica: Escuchamos la palabra divina que es la salvación (Salmo 50 y Luc 11,28). Las profecías se cumplen con el nacimiento de Cristo (Luc 2,8. Luc 3. Mat 3). En la Encarnación la palabra se hizo carne (Luc 1,26). Las almas de los difuntos (las aves) van al cielo. Se guarda fidelidad a María (orante con perro). Cristo resucita como el ciervo y como Orfeo.

El oído es la fuente de todo conocimiento: La música vocal es superior a la música instrumental (Marsias). El oído presenta la verdad desnuda (la Ninfa está desnuda). La elocuencia musical todo lo puede (Orfeo y el papagayo). El oído supera en ocasiones a la vista (al lince). La esfera celeste se rige por la armonía divina y musical. Las partituras (la escritura) nos muestran la regla verdadera y el camino de la concordia.

Pero a veces conviene desconfiar: La Fama tiene dos trompas y llena los oídos de verdades y de mentiras. El ciervo, como el unicornio, a veces se deja apresar por la adulación. La riqueza y el poder solo son vanidades, pues todo pasa (relojes). Hay que limitar la elocuencia (el loro está en su jaula).

Y siguiendo tan sabio consejo, concluye aquí está interpretación musical y retórica de $L a$ Alegoría del Oído de Jan Brueghel «de Velours».

Víctor Pliego de Andrés Conservatorio «Arturo Soria» de Madrid

\title{
EL GRABADO ITALIANO EN EL LIENZO «LA ADORACIÓN DE LOS REYES MAGOS», DE FRANCISCO CAMILO
}

En 1914 fue depositado en el Museo de Bellas Artes de Bilbao un cuadro, donativo del ingeniero y conocido coleccionista de arte don Laureano de Jado ${ }^{1}$. En él se nos representa una escena del Nuevo Testamento, «La Adoración de los Reyes Magos» ${ }^{2}$ (Fig. 1), que, en el momento de su ingreso, estaba atribuido a Francisco Rizi. Estudios posteriores, tanto técnicos como estilísticos llevados a cabo por el profesor Diego Angulo Íñiguez ${ }^{3}$ a cerca de la obra completa del pintor Francisco Camilo (1615-1671) parecen no ofrecer duda alguna sobre la autoría de este lienzo por el artista madrileño. Incluso llegó a relacionar esta obra con otra que el propio Camilo realizó en una iglesia de la localidad castellana de Getafe y en general con toda la producción del artista pintor en donde se puede apreciar una importante influencia del mundo artístico ita-

1 Don Laureano de Jado, ingeniero de minas vinculado a los pueblos de Munguía y Erandio (donde se conservan instituciones a las que él contribuyó); fue un prestigioso coleccionista de arte y generoso donador que contribuyó de forma importante a la fundación del Museo de Bellas Artes de Bilbao (8 febrero 1914) y sobre todo a la amplicación de sus colecciones... Velez López, Oloina. "La creación del Museo de Bellas Artes de Bilbao», en Anuario del Museo de Bellas Artes de Bilbao, pp. 9-20 (1993).

2 "La Adoración de los Reyes Magos", atribuida a Francisco Camilo, ejecutada entre 1660-1670, óleo sobre lienzo 83. $119 \mathrm{~cm}$, donación de don Laureano de Jado, en 1914, n. ${ }^{\circ}$ inv. 69/43.

3 Angulo Íñiguez, Diego, "Un cuadro de Francisco Camilo en el Museo de Bellas Artes de Bilbao»; Archivo Español de Arte, n. ${ }^{\circ} 139,1962$, p. 271. 


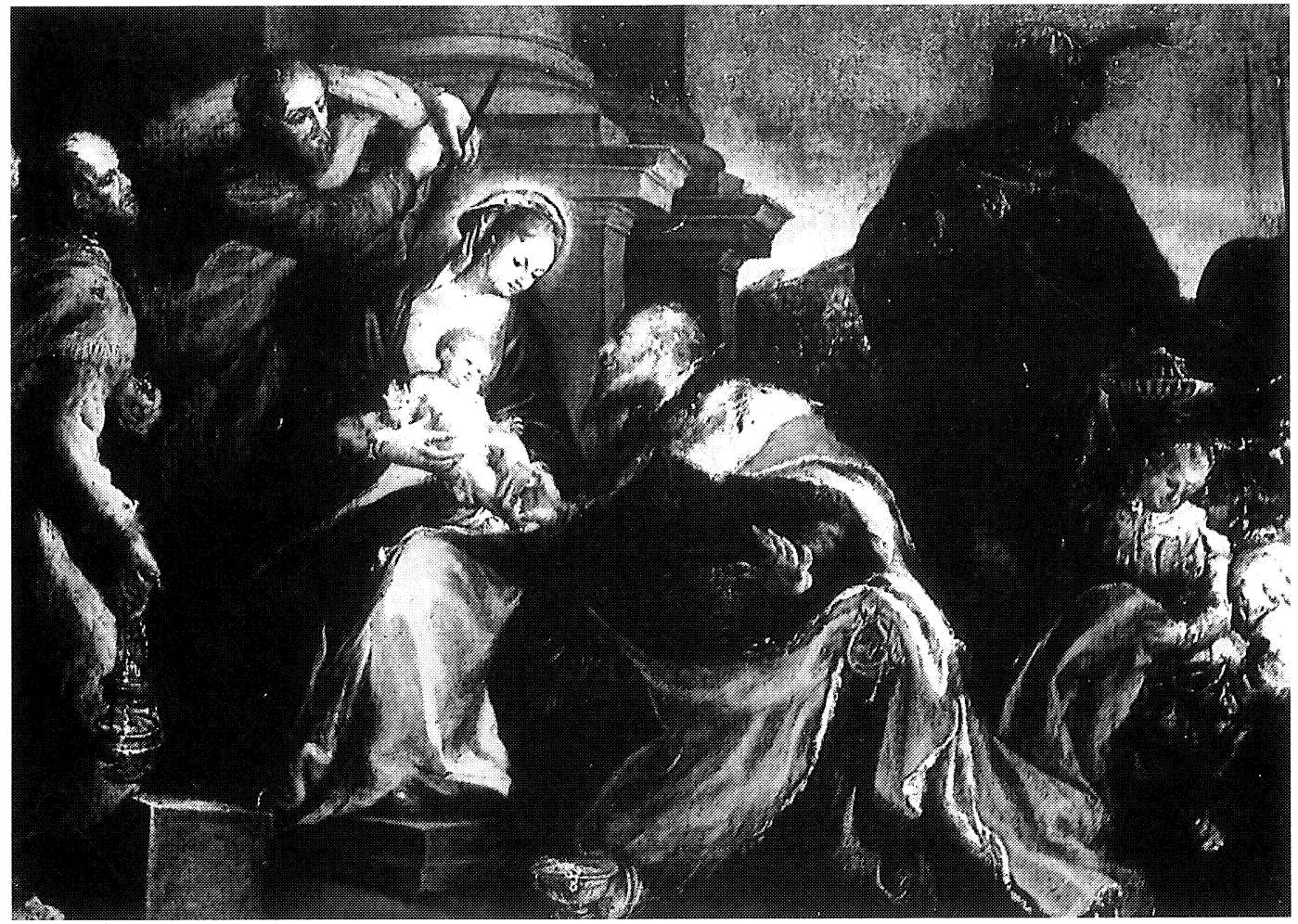

1

2
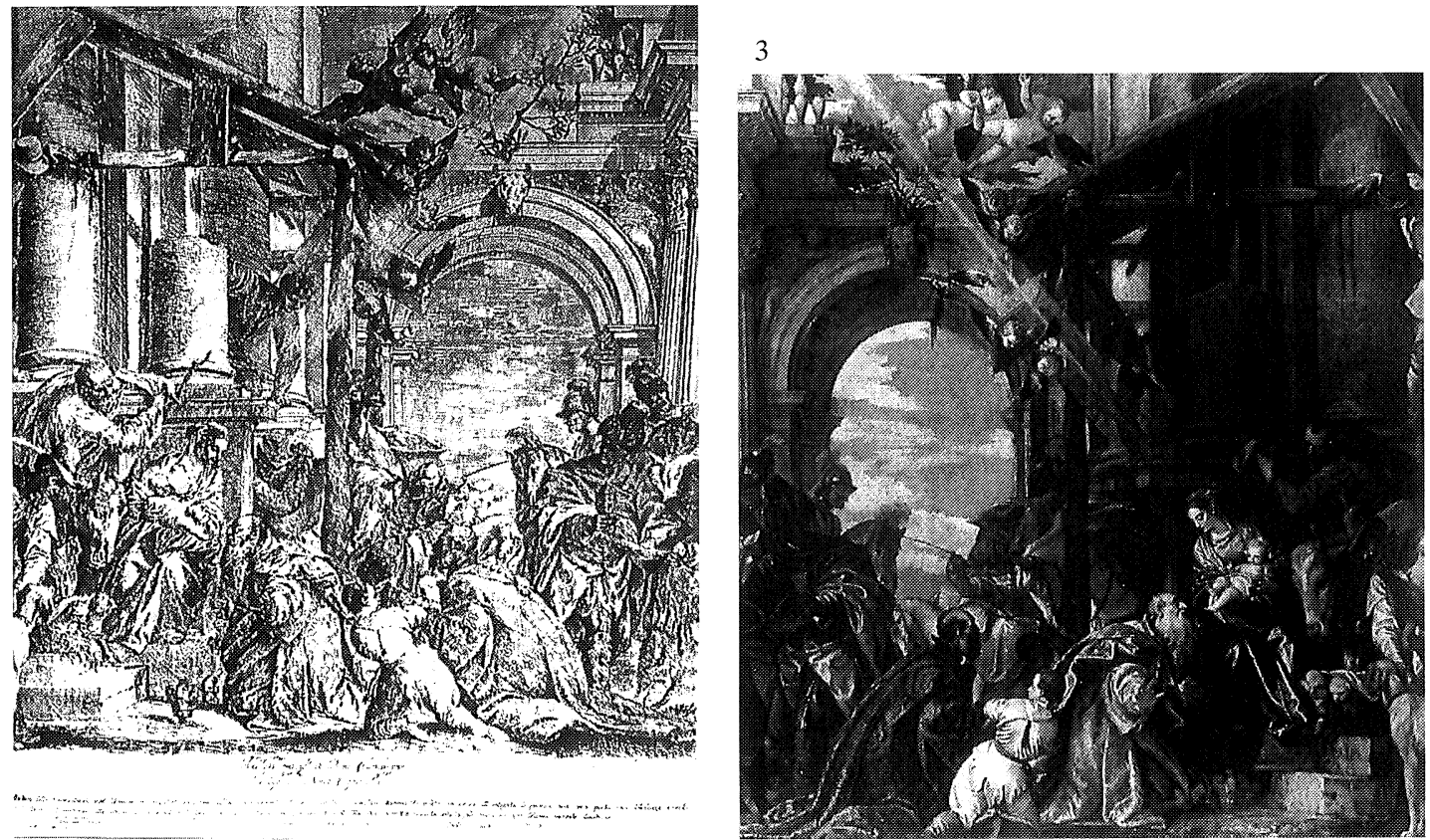

Fig. 1. Francisco Camilo, La Adoración de los Reyes Magos. Bilbao (Vizcaya), Museo de Bellas Artes de Bilbao. Fig. 2. Carlo Sacchi, La Adoración de los Reyes Magos. Viena.

Fig. 3. Paolo Caliari, "el Veronés», La Adoración de los Reyes Magos. Londres, Nacional Gallery. 
liano y más concretamente de la pintura veneciana, reflejándose, en este caso concreto, en la luz y el colorido de los paisajes con unas tonalidades aurea y azuladas.

No olvidemos que nuestro artista fue hijo de Doménico Camilo, natural de Florencia, lo que puede ser significativo a la hora de afirmar que el conjunto de sus obras, una importante producción ${ }^{4}$, nos revelan a un pintor que se encuentra más cercano al arte italiano que al madrileño, queda esto claramente definido en esta obra del Museo de Bellas Artes de Bilbao donde denotamos una clara tendencia técnica y compositiva, por parte de Francisco Camilo, hacia el artista veneciano Pablo Veronés, siendo lógico pensar que Camilo conociera bien su obra existiendo, en este sentido, una doble posibilidad por la que o bien el madrileño conocía insitu y de forma directa las obras del pintor veneciano, justificado probablemente por algún viaje a Italia, o lo que es más factible desde mi punto de vista, que Camilo utilizara uno de los tantos grabados que sobre la obra del Veronés se hicieron, siendo éste un medio más práctico, cómodo y barato de conocer las obras de los grandes maestros de la pintura europea, destacando así la importancia que la difusión de estampas por toda Europa tuvo en el mundo del arte, por lo que no cabe extrañar que Francisco Camilo también jugara dentro de estos parámetros.

Me remito a esta idea para defender la hipótesis de que el cuadro atribuido a Francisco Camilo bajo el título «La Adoración de los Reyes Magos» depende, por lo que a su composición se refiere, de un grabado perteneciente al italiano Carlo Sachi (Fig. 2) que reproduce fielmente un cuadro de Pablo Veronés sobre el mismo tema ${ }^{5}$ (Fig. 3).

Carlo Sachi, quien nació y murió en Padua (1616-1706), reprodujo en sus estampas esta y otras obras del Veronés, siendo después explicable el que llegaran estas imágenes a manos de nuestro pintor madrileño, dado el importante trasiego comercial de grabados que se daba en Europa en estos momentos, y le interesaran con el fin de utilizarlas como modelo para desarrollar posteriormente, en el caso del cuadro bilbaíno, la composición central del mismo compuesto por la diagonal constituida por San José, la Virgen con el niño y el rey mago arrodillado, Melchor; existe alguna pequeña variante pero en su conjunto no hay duda alguna sobre la conexión habida entre ambas imágenes.

Un punto de gran consideración, que refuerza aún más si cabe esta hipótesis, a la hora de pensar que Francisco Camilo pudo utilizar el grabado de Sachi como modelo para componer este cuadro y que por tanto no vio directamente el lienzo del Veronés, es que Camilo ejecuta su obra en el mismo sentido que en el grabado, es decir, la diagonal formada por los personajes centrales de la composición baja de izquierda a derecha en ambos casos mientras que en el cuadro de Pablo Veronés lo hace de forma inversa.

Este fenómeno, la utilización del grabado como modelo o base de una composición artística, fue muy llevado a la práctica por los artistas españoles del momento, no debiéndose dejar pasar por alto la importancia que en el mundo del arte tuvo la estampa y su difución por el continente europeo.

Fernando Morente LuQue Instituto Ephialte

\footnotetext{
4 Palomino, Antonio, Vidas, Alianza ed., Madrid, 1986, pp. 232-235.

5 “La Adoración de los Reyes Magos" de Pablo Veronés se encuentra e la National Gallery de Londres fechado hacia 1573 y que en su origen se encontraba en la Iglesia de San Silvestre (Venecia), pero tras su reorganización arquitectónica fue retirada y vendida en 1855 al marchante Toffoli a quien ese mismo año se lo compra la galería londinense.
} 